\title{
The first fossil Aristolochia (Aristolochiaceae, Piperales) leaves from Austria
}

\author{
Barbara Meller
}

\begin{abstract}
The first reliable leaf remains of Aristolochia from Late Miocene sediments in Austria are described as $A$. austriaca nov. spec. Comparative investigations with about 80 extant species of Aristolochia and with selected genera of other families support the generic identification. Fossil leaves from Europe, North America and China formerly identified as Aristolochia or Aristolochites were compared to the new fossils. None of these are similar to the new species from the Pellendorf site at the northwestern margin of the Vienna Basin. The sedimentary environment and the associated fossils indicate a habitat within or near wetland environments. $A$. austriaca is most similar to the extant $A$. rotunda and $A$. baetica and might point to a relationship to those Mediterranean species and their origin.
\end{abstract}

Barbara Meller. Institute of Palaeontology, University of Vienna, Althanstr. 14, 1090 Vienna, Austria; email: barbara.meller@univie.ac.at

Keywords: Basal angiosperm; new species; fossil record; Miocene; systematic; palaeoecology

\section{INTRODUCTION}

The Aristolochiaceae are a conspicuous family with distinctive and showy flowers positioned among the basal angiosperms (APG III, 2009; figure 1, APG II, 2003). The family is divided with a total of four to twelve genera and 500 to 600 species, depending on classification; 400 to 500 of those species belong to the subfamily Aristolochiodeae and nearly 100 to the Asaroideae (Neinhuis et al., 2005; Wanke et al., 2006). The latter are distributed mainly in northern temperate regions with East Asia as centre of diversity, the former mostly in tropical to subtropical species-rich areas in Cen- tral and South America (Schmidt, 1935). Aristolochia comprises about 120 (Huber, 1993) or 400 to 500 (Wanke et al., 2006) species depending on the differentiation within the subgenera. The plants grow as perennial rhizomatous herbs or deciduous or evergreen shrubs and lianas. Today, Aristolochia is represented in Austria with one species, A. clematitis, growing in different areas and assemblages such as the margins of wetland forests and margins of vineyards (Fischer et al., 2008 and personal observations). It is regarded as an archaeophyte in Austria and also in Germany, Switzerland and Great Britain with records extending back to medieval times (Fischer et al., 2008; Lauber and Wag-

PE Article Number: 17.1.21A

Copyright: Palaeontological Association May 2014

Submission: 14 July 2013. Acceptance: 20 March 2014

Meller, Barbara. 2014. The first fossil Aristolochia (Aristolochiaceae, Piperales) leaves from Austria. Palaeontologia Electronica Vol. 17 , Issue $1 ; 21 \mathrm{~A} ; 17 \mathrm{p}$;

palaeo-electronica.org/content/2014/718-aristolochia-from-austria 


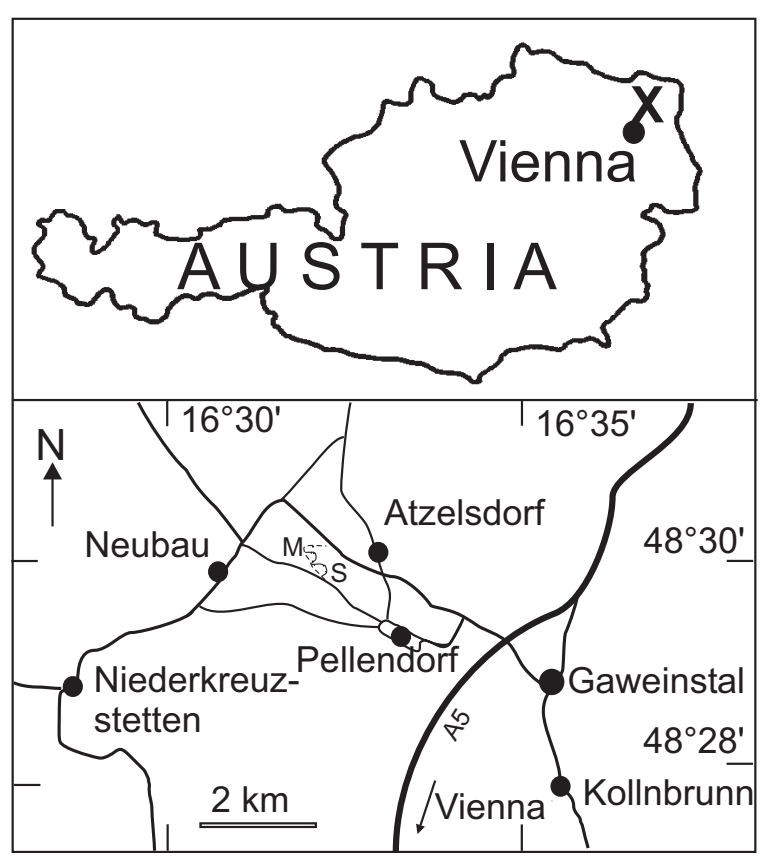

FIGURE 1. Geographical position of the type locality Pellendorf in Austria in an overview ( $X=$ position of Pellendorf) and exact map ( $\mathrm{M}=$ sandpit $\mathrm{Max}, \mathrm{S}=$ sandpit Semrad).

ner, 1996). The origin of the species was probably not the Mediterranean area according to Wanke (2006). The species was disseminated and cultivated for medicinal use.

The fossil history of Aristolochia is poorly known and fossil leaf records are rare (e.g., van der Burgh, 2005; LaMotte, 1952), documented mainly with single specimens which are often ambiguous. The Aristolochiaceae are not dealt with by Taylor et al. (2009) and Mai (1995) mentioned Aristolochia only once, but without giving any details. The oldest leaf remains assigned to the Aristolochioideae came from the Late Cretaceous of Nebraska, USA (Aristolochites dentata Heer in Capellini and Heer, 1867) but the systematic affinities are in need of critical review. The fossil leaf records of Aristolochia from Central Europe will be discussed in detail below. Pollen records are nearly missing probably because the plants are entomophilous and produce fewer pollen grains than anemophilous plants. The oldest and only pollen record of the Aristolochioideae was recently described from Upper Cretaceous sediments of Siberia (Aristolochiacidites viluiensis Hofmann and Zetter, 2010). Fossil fruit remains from Europe were rejected by Kirchheimer (1957) and seed records are still lacking.

The first occurrence of reliable fossil leaf remains of Aristolochia from Austria represents an important contribution to the fossil history of Aristolochia and extends the floral spectrum of the Miocene vegetation.

\section{GEOLOGICAL BACKGROUND}

The investigated leaf fossils derive from the northwestern margin of the Vienna Basin. This basin developed by tectonical extension during the developing alpine orogeny at the northwestern edge of the Central Paratethys. The retreat of the marine Paratethys sea at the end of the Middle Miocene led to fresh water depositions in lakes and rivers. A braided river system belonging to the so called "Palaeo-Danube" river with a wide deltaic plain was established during the Pannonian Zones C/D (early Late Miocene, at about $11 \mathrm{Ma}$ ) according to Harzhauser et al. (2003, figure 6). Gravels, sand, silt and rarely clay of the Hollabrunn-Mistelbach Formation were deposited. The sand pits "Max" and "Semrad" near Pellendorf (about $45 \mathrm{~km}$ NNE of Vienna, Figure 1) exposed $35 \mathrm{~m}$ of this formation. Their detailed geological and palaeoecological investigations recognized five sedimentary units characterized by sedimentological and palaeontological changes, caused by lake level fluctuations (Harzhauser et al., 2003). River sediments were replaced by lake and freshwater marshes and finally by fine-grained offshore deposits (KovarEder et al., 2002). Plant remains have been mainly found in lithozone unit 3 often consisting of unidentifiable plant detritus but also of well-preserved leaf impressions (Decodon, Mikia Kovar-Eder and Wojcicki in Kovar-Eder et al., 2002; Populus, Ulmus), fruit impressions and compressions (Ceratophyllum, Hemitrapa Miki, 1941, Potamogeton, Trapa), shoot impressions of Ceratophyllum, rhizome impressions of Nymphaeaceae and three dimensionally preserved charophyte oogonia. The nearby gravel pit "Semrad" provided in addition leaf imprints of Taxodium and Smilax (Harzhauser et al., 2003; Kovar-Eder et al., 2002). The investigation of sediment blocks for coalified carpological remains as well as ongoing collections by private collectors yielded additional yet unpublished elements such as e.g., Alismataceae, Cephalanthus, Eoeuryale Miki, 1960, Microdiptera Chandler, 1957, Moraceae, Phyllanthus, Platanus, Rosa, ? Sapindoidea Kirchheimer, 1936, and Vitis.

\section{MATERIAL AND METHODS}

\section{Material}

The Aristolochia leaf impressions were found in loose silty blocks of sediment of light yellow to 
yellow to light brown colour in front of the northern wall of the sand pit "Max" in 2004. Two leaves are located within the same block and occur more or less in the same layer, one with its counterpart (Figures 2, 3, 4); a third fragmentary problematical specimen occurs in a separate small block (Figure 5). The sediment surface with the leaves seems to be finely bedded at a first sight, but in detail a distinct relief can be observed. Additionally, the large block with the two specimens includes less wellpreserved fragments of leaf impressions of Decodon and Salix, fruits or fruit fragments of Trapaceae compressions and impressions, an impression of a large wood fragment and small fragments of mollusc shells. This assemblage indicates that the blocks with the leaf impressions derive from the lithozone unit 3 (Harzhauser et al., 2003, table 1).

\section{Methods}

Two comparative studies were carried out: 1 . the comparison with extant taxa with similar morphological characters to confirm the generic identity, and 2. the comparison with the fossil Aristolochia species based on leaves to distinguish the new species clearly from all the others. Different families and genera have similar leaf shapes, such as Aristolochiaceae, Saururaceae, Smilacaceae, Dioscoreaceae, Convolvulaceae, Polygonaceae and Menispermaceae. Schimper and Schenk (1890) already mentioned the lack of unique features of Aristolochiaceae leaves and additionally noted that also in the Melastomataceae, Urticaceae and Piperaceae similar leaf shapes can occur. About 80 extant species of Aristolochia and several species of Asarum, Dichondra and Calystegia were studied in the herbaria of the Natural History Museum Vienna (W), the Botanical Institute of the University of Vienna (WU) and the University of Florida at Gainesville (FLAS). Recently the virtual herbaria of these institutions and also those from the Royal Botanical Garden Kew, the New York Botanical Garden and the Herbarium Berolinense were checked for the determination of the fossil leaves and the variability of leaves on one shoot. The search for published fossil Aristolochia species was supported by the Fossilium Catalogus Plantae (van der Burgh, 2005) and the catalogues of North American Cenozoic plants (LaMotte, 1952; and former catalogues cited there).

The material was studied with Leica binocular microscopes and the drawings were carried out with the camera lucida or by tracing the photographs. Images were obtained with a Canon Powershot camera and manipulated in size, brightness and contrast. The descriptive terminology follows Hickey (1979).

The authors of fossil genera and species are cited together with the year of publication when the taxon is mentioned for the first time within the text. The publications are listed within the references. Extant taxa are generally mentioned without author and year of publication apart from the systematic part. The references of extant taxa are cited according to the IPNI database (International Plant Name Index, 2012) not by personal view. The status of extant species was checked at The Plant List homepage (The Plant List, 2010). The classification follows APG III (2009) wherein the Magnoliids are treated as informal group.

The material is stored in the collection of the Geological Survey of Austria (GBA).

\section{RESULTS}

\section{Systematic description}

\author{
Magnoliids \\ Order PIPERALES Berchtold and J. Presl, 1820 \\ Family ARISTOLOCHIACEAE Jussieu, \\ 1789 nom. cons. \\ Genus ARISTOLOCHIA Linnaeus, 1753 \\ Aristolochia austriaca nov. spec.
}

Figures 3, 4, 5

Holotype: GBA 2008/085/0001a (Figure 3).

Paratype: GBA 2008/085/0001b with counterpart (Figure 4).

Locus typicus: Sand/gravel pit "Max", NW Pellendorf and $E$ Neubau, about $45 \mathrm{~km}$ NNE of the centre of Vienna, Mistelbach district, Lower Austria, $16^{\circ}$ $32^{\prime} 04^{\prime \prime} \mathrm{N}, 48^{\circ} 29^{\prime} 57^{\prime \prime}$ E.

Stratum typicum: Hollabrunn-Mistelbach Formation, Pannonian C/D, Lower Pannonian, Upper Miocene.

Etymology: The species name refers to Austria as the country of occurrence.

Material: Two leaves, one with counterpart. A third fragmentary specimen is doubtful (GBA 2008/085/ 0002).

Diagnosis. Lamina broadly ovate, about $3 \times 3 \mathrm{~cm}$ in size, base lobate, apex rounded and retuse, margin entire; venation basal actinodromous, upwards brochidodromous; course of the lateral primary veins slightly zigzag distally or turning towards the apex, tertiary veins roughly perpendicular to primary and secondary veins with a slightly curved course; venation of higher order an often orthogonal network, marginal venation looped.

Description: Leaves are with or without a very short petiole (Figures 3, 4). Laminae are entire-mar- 


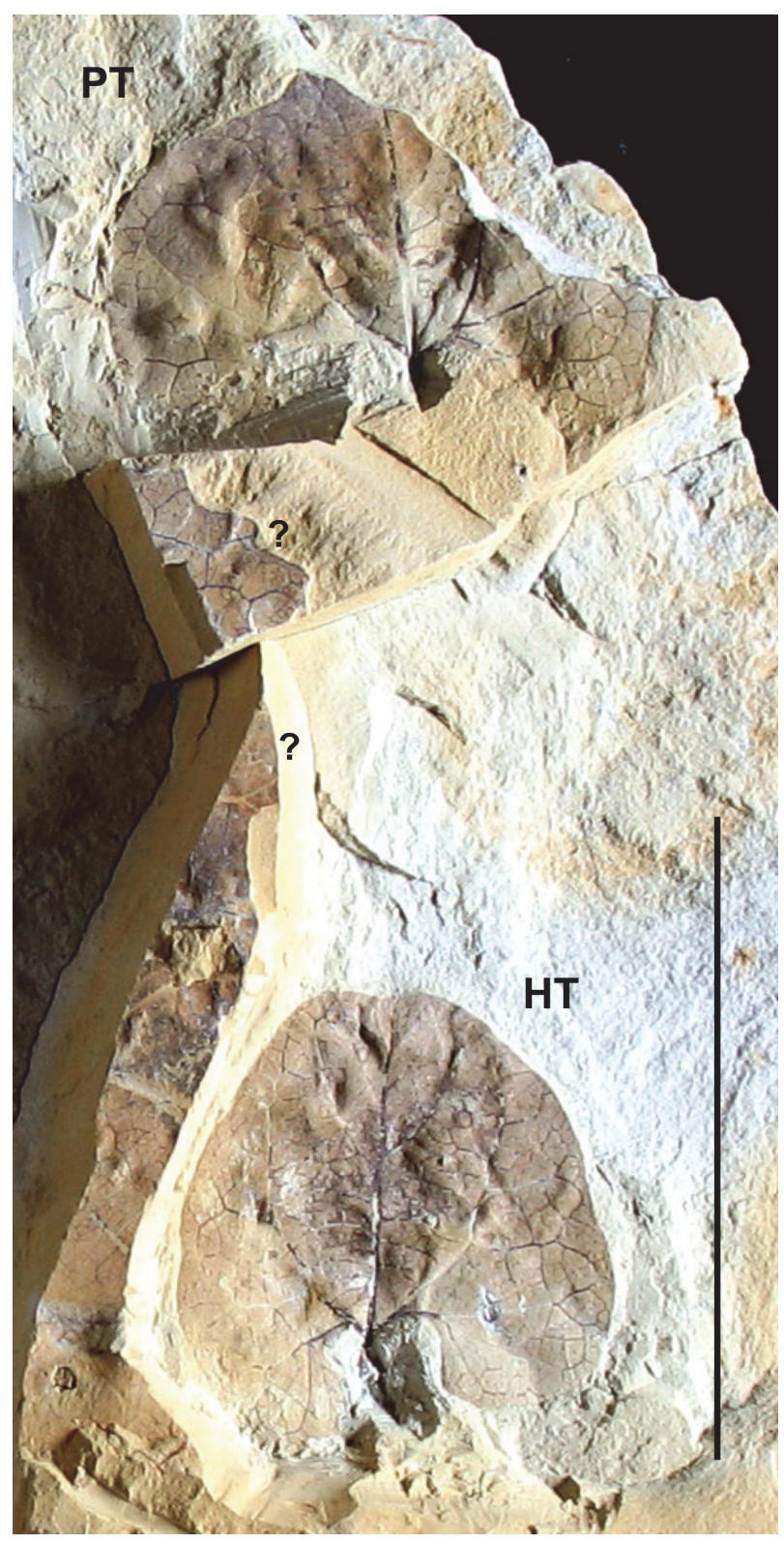

FIGURE 2. Part of the sediment block with the two leaves of Aristolochia austriaca nov. spec. in the same layer, (GBA 2008/085/0001a, b), scale bar $5 \mathrm{~cm}, \mathrm{HT}=$ holotype, $\mathrm{PT}=$ paratype, ? = unidentifiable leaf fragments in a different layer.

gined, broadly ovate, nearly circular and symmetrical to slightly asymmetrical in shape, 2.6 and $3 \mathrm{~cm}$ long, 3 and $3.6 \mathrm{~cm}$ broad. The lamina base is lobate and slightly decurrent, apex rounded and retuse. Primary venation consists of three veins, which diverge at the lamina base at $50-55^{\circ}$. The course of the lateral primary veins turns upwards into a more apical direction and can be slightly zigzag (Figure 3 ) or may turn apically inward into the direction of the mid vein (Figure 4). Secondary venation is brochidodromous. The spacing of the secondary veins at the middle primary vein is irregular. The distance between lamina base and first pair of secondary veins is about half of the length of the primary vein. The lateral primary veins have secondary veins in varying distances towards the lamina margin. The first secondary vein is nearly as thick as the primary vein. Tertiary veins are more or less orthogonal to the primary and secondary veins with a more or less curved course. The venation of higher order builds a network of often orthogonal areoles. The marginal veins are recurved and looped, not entering the margin.

Differential Diagnosis. Aristolochia primaeva Weber, 1852 (Rott, Germany, Oligocene) is represented only by a basal leaf fragment. It differs by its cordate base and the regular spacing of the secondary veins in the lower part of the lamina. Aristolochia hastata Weber in Wessel and Weber, 1856 (Rott, Germany, Oligocene) has a more elongate lamina with a sagittate base. Aristolochia dentata Weber in Wessel and Weber, 1856 (Rott, Germany, Oligocene) is based on a fragmentary leaf which differs by its serrate margin. Aristolochia aesculapi Heer, 1856 from Switzerland (Hoher Rhonen, Miocene) differs by its cordate-sagittate base and the course of the lateral primary vein running downwards from the lamina base into the basal lobe building a well-developed arch. Aristolochia nervosa Heer, 1859 (Hoher Rhonen, Switzerland, Miocene) is based on one fragmentary leaf and differs by a more elongate shape and the secondary veins, which are forking early and forming distinct arches. Aristolochia wetzleri Heer, 1859 (Günzburg, Germany, Miocene) is described in a footnote, but not figured. It is mentioned as similar to $A$. primaeva but with a decurrent base and therefore not comparable to the new species. Regularly spaced secondary veins and a partly crenate margin are visible in A. taschei Ludwig, 1859 from Salzhausen (Germany, Miocene) and differs it from the new species. The leaf of $A$. venusta Saporta from Radoboj (Croatia, Miocene) (figured in Schimper 1874 , plate 106 , figure 36 ) is clearly distinguishable by its ovate shape, the cordate base and acute apex. Aristolochia borealis Heer, 1874 from Greenland (Palaeocene) is based on two leaf bases. Later in 1883 Heer figured one more fragment from the Cretaceous. They differ by their several primary veins. Aristolochia inaequalis Heer, 1883 from Greenland (Eocene) is based on a nearly complete leaf, but the loops and arches of the secondary veins, their narrow spacing and the 

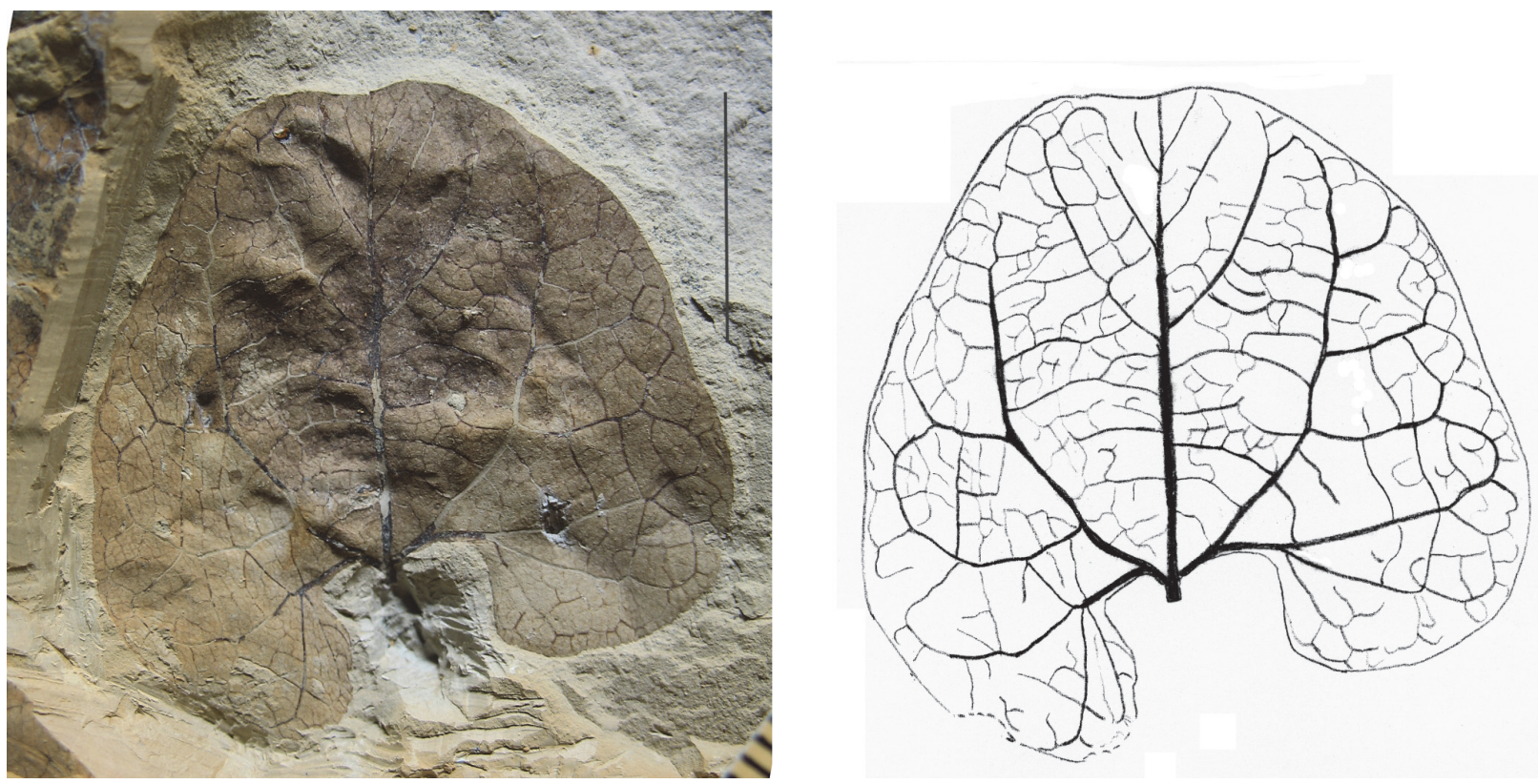

FIGURE 3. Holotype of Aristolochia austriaca nov. spec., GBA 2008/085/0001a, scale bar $1.3 \mathrm{~cm}$.

obtuse angles between the primary and the tertiary veins are not comparable to the Pellendorf specimens. Aristolochia sanctae-juistinae Principi, 1916 (refigured and confirmed by Gregor and Knobloch, 2001, figure 74) from Italy (Oligocene) has many secondary veins in short and regular distances. Aristolochia nógrádensis Andréansky, 1959 was described from a Middle Miocene deposit of Hungary and has a triangular lamina shape in contrast to the circular to broad ovate one of the Pellendorf specimens. Two fossil species from the former USSR are mentioned by Takhtajan (1974): Aristolochia africani Kolakovsky, 1956 and A. colchica Kolakovsky, 1964 (original references not studied). Both species differ by their larger size and their ovate to elliptical lamina shape. The lamina base of the former species is cordate, whereas A. colchica shows a lobate base. Aristolochia pliocaenica (Givulescu and Ticleanu, 1978) Knobloch, 1998 and "cf. A. venusta Saporta," 1881 (original reference not studied) were described by Knobloch (1998) from the locality Willershausen (Germany, Pliocene). The larger lamina and the venation of $A$. pliocaenica with its more regularly spaced secondary veins are different from the Pellendorf specimens. The leaf determined as cf. $A$. venusta has a cordate base and a long acute to attenuate apex in contrast to the lobate base and rounded, retuse apex of the Pellendorf specimens. From Bilina (Czech Republic) Kvaček et al. (2004) listed Aristolochia sp., without any descriptions or figure. An unpublished picture of this specimen (kindly provided by Dvorak Zdenek) shows a lamina with regularly spaced secondary veins and a fragmentary base.

Aristolochia shanwangensis Tao, Sun and Yang in Sun, 1999 from Shanwang (China, Miocene) differs from the Pellendorf specimens by its more ovate-triangular shape and the rounded or only slightly cordate base. The figured specimen (Sun, 1999, plate 3, figure 4) has a nearly truncate base.

Aristolochia mortua Cockerell, 1908 (Florissant, USA, Oligocene) is larger and with an acute apex. The leaves of " $A$. ? coloradensis" Knowlton, 1917 (Colorado, USA) are much larger and broadly ovate in shape with an acute apex. A. brittoni Knowlton, 1922 (Laramie, USA, Eocene) is documented by fragmentary remains, with less wide lobes than the Pellendorf specimens. Aristolochia pagei Hollick in Hollick and Martin, 1930 (Alaska, Cretaceous) is much larger in size and the base is not preserved. Aristolochia mexiana Chaney and Sanborn, 1933 (Goshen, Oregon, USA, Oligocene) has large, elongate leaves with a cordate base. Aristolochia triangularis MacGinitie, 1937 (nomen nudum) (Weaverville beds, California, USA) is broadly ovate with an only slightly lobate base. Aristolochia claiborniana Berry, 1924 is broadly ovate with a cordate base and several secondary veins in the basal part of the leaf. It looks similar to A. primaeva. 

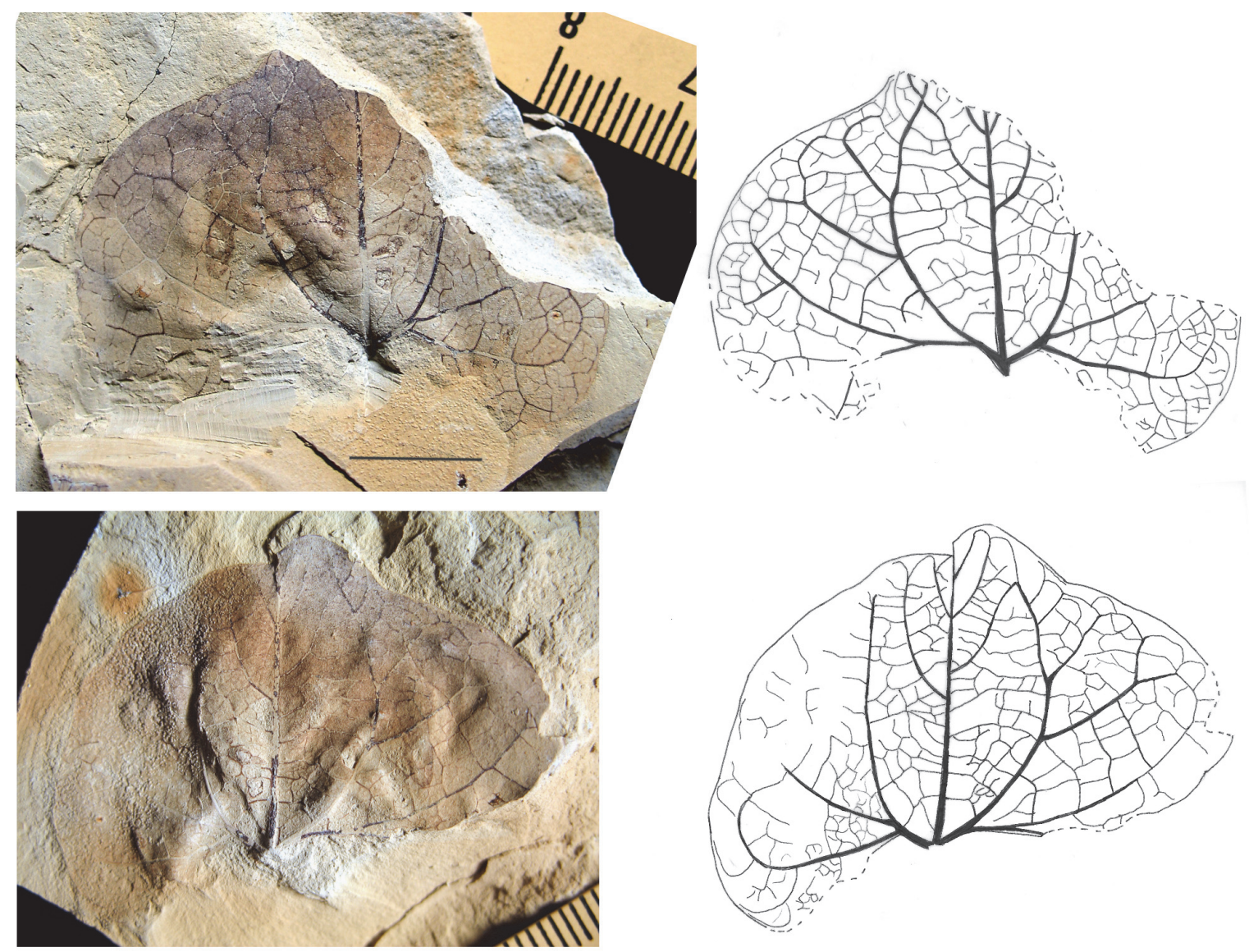

FIGURE 4. Paratype of Aristolochia austriaca nov. spec., (upper row) GBA 2008/085/0001b; and its counterpart (lower row), scale bars $1 \mathrm{~cm}$.

\section{Comparisons with Extant Aristolochia Leaves}

The leaves of extant Aristolochia Linnaeus, 1753 plants show very variable lamina shapes from long lanceolate, elliptical to nearly circular or triangular and ovate as well as obovate or trilobate and also variable sizes. The heterophylly on one stem or shoot has been already observed by Pfeifer (1966). Moreover leaves of the same species from different localities can display a certain amount of variation. In the investigated herbarium specimens the species with leaf shapes resembling the fossil type are generally petiolate but some herbaceous species can be without or with just a short petiole (e.g., A. rotunda Linnaeus, 1753). The texture of the leaves is often thin and fragile but thicker and coriaceous leaves also occur. The apex varies from acute, slightly retuse to rounded, the base is wide obtuse and lobate (= auriculate) sometimes cordate, often shortly decurrent, very rarely straight. Some descriptions use the term cordate for the lobate base shape, and the lobes are called auricles, which can be converging or diverging (e.g., Nardi, 1984, 1991). The lamina margins are entire or slightly undulate in dried condition. Nardi (1984) described A. clematitis Linnaeus, 1753 as minutely toothed from Italy. The venation varies from mainly actinodromous to nearly acrodromous to brochidodromous or campylodromous. The angle between the middle and the lateral primary veins is between 25 and $60^{\circ}$, often wider at the base, with the lateral veins becoming turned towards the apex. Secondary veins occur mainly on the distal part of the midvein, rarely already in the lower part (Figure 6.2). At the lateral primary veins the secondary veins occur only towards the lamina margin. The tertiary venation between midvein and lateral veins arises often more or less perpendicular to midvein and lateral veins with an arch in the middle. The venation of higher order is variable.

Leaves of some extant Mediterranean species are most similar to the Austrian fossils: e.g., Aristolochia rotunda (Figure 6.2-4), A. sempervirens Linnaeus, 1753 (Figure 7) and $A$. baetica Linnaeus, 1753 (Figures $6.5,8,9.1$ ). A. rotunda generally has 

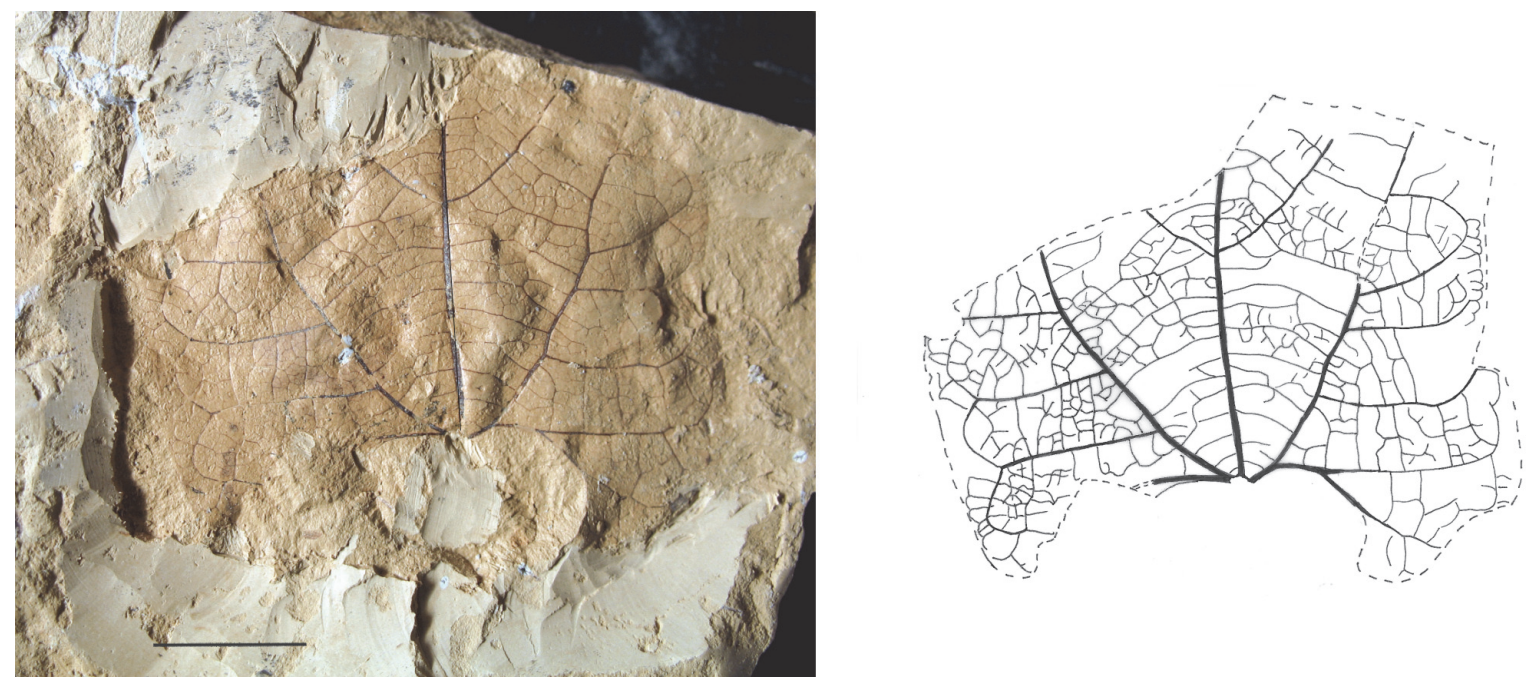

FIGURE 5. cf. Aristolochia austriaca nov. spec., GBA 2008/085/0002, scale bar $1 \mathrm{~cm}$.

circular laminas with a rounded and retuse apex. Aristolochia baetica has leaves which are mainly longer than wide with acute or rounded apex (Figure 8, Klucking, 1995, plate 13, figure 4). If the lamina is infolded in its apical part a more circular shape is shown (Figure 8.3). Another voucher presents laminas, which are all nearly circular, mainly wider than long with a rounded apical area (Figure 9.1). In A. sempervirens the laminas are longer than wide, mostly ovate in shape, with an acute apex. One voucher included one leaf near the base of the plant whose shape, base and venation is like that of the $A$. austriaca holotype (Figures $7,6.1)$. Such variation cannot be assumed for the fossil species. Both fossil leaves are more circular and the length/width ratio is about 1 or smaller. This indicates that the fossil species has generally leaves of this type and that the fossil leaves do not represent unusual basal leaves. The apical area of the paratype (Figure 4) is incomplete and might be slightly infolded, hiding the true shape of the apex, similar to many membraneous Aristolochia leaves in the herbaria (Figure 8.3). The slightly variable course of the lateral primary veins of the two fossils has also been observed in different specimens of one species in the herbaria. Other less widespread Mediterranean species fit also in lamina shape, base, apex and venation (e.g., Aristolochia guichardii P.H. Davis and Khan, 1964, A. cretica Lamarck, 1783, A. incisa Duchartre, 1864, A. microstoma Boissier and Spruner, 1844, A. clusii Lojacono, 1907, A. insularis Nardi and Arrigoni, 1983, A. bianorii Sennen and Pau, 1921 etc.) according to the figured specimens in Nardi (1984, 1991). The two latter are regarded as derived from
A. rotunda or as geographic vicariants (Nardi, 1984).

Leaves of broad ovate to triangular shape which are as long as wide occur also in non Mediterranean species e.g., Aristolochia clausenii Duchartre, 1854, A. littoralis Parodi, 1878), A. labiata Willdenow, 1809, A. ridicula N.E. Brown, 1886 (species not included in The Plant List), or $A$. ringens Vahl, 1794 but they show an obtuse to acute or slightly mucronate apex, or less distinct lobes of different shape or more than three primary veins. Leaf laminae wider as long have also been observed e.g., in Aristolochia bridgesii (Klotzsch) Duchartre, 1864 (W Herb. Cumin.) (Figure 9.2) and A. chilensis Miers ex Lindley (Figure 9.3) (author according to the herbarium label; The Plant List regards $A$. chilensis Bridges ex Lindley, 1834 as accepted taxon). However, the secondary veins are different. The latter one has regularly forking secondary veins and the former one show secondary veins also in the lower part of the midvein. More variable in shape and size are the leaves of Aristolochia species from E Asia, Australia or America where also lanceolate to narrow elliptical leaves with narrow rounded bases occur (e.g., Barringer, 1997; Hou, 1983, Parsons, 1996; Shumei et al., 2003, A. westlandii Hemsley, 1885; see also the virtual herbaria of W, WU, FLAS and others). The leaves show a different secondary venation with regular spacings from the base to the apex. Even leaves with obovate laminae such as in $A$. maxima Jacquin, 1760 or even trilobate ones as in A. trilobata Linnaeus, 1753 occur.

The second subfamily of Aristolochiaceae, the Asaroideae, also has leaves of a general similar 
1

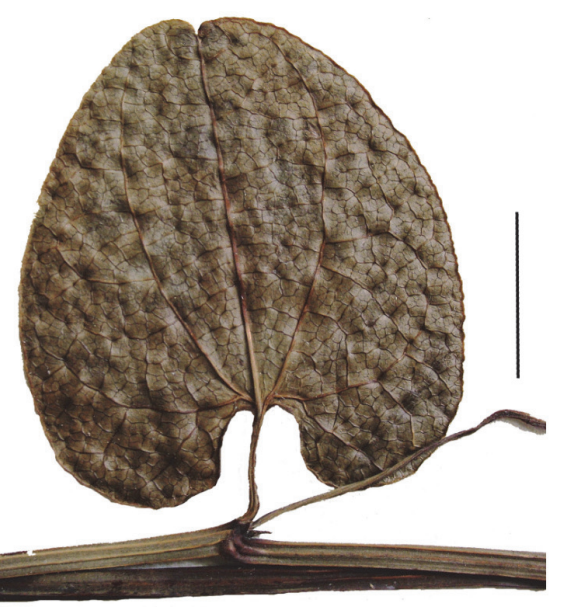

3

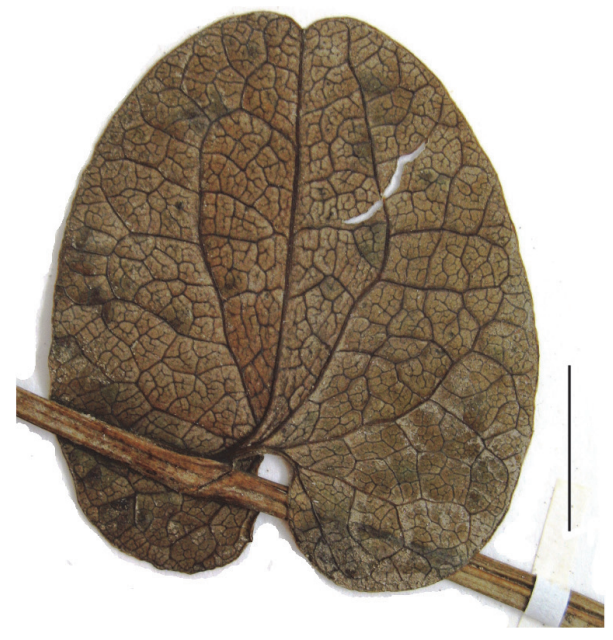

5

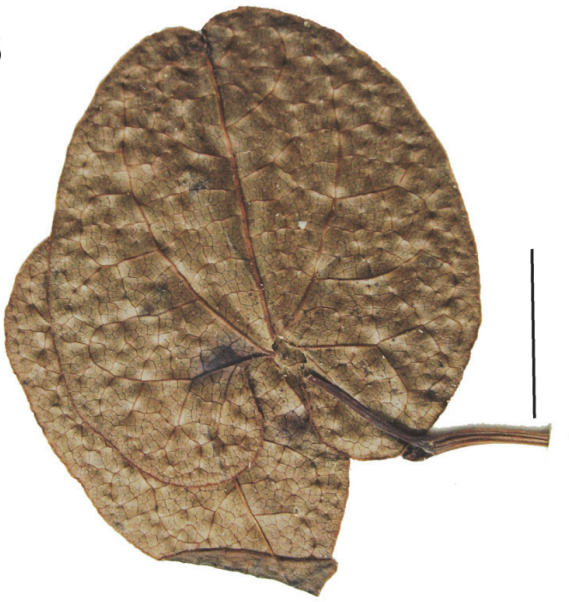

2

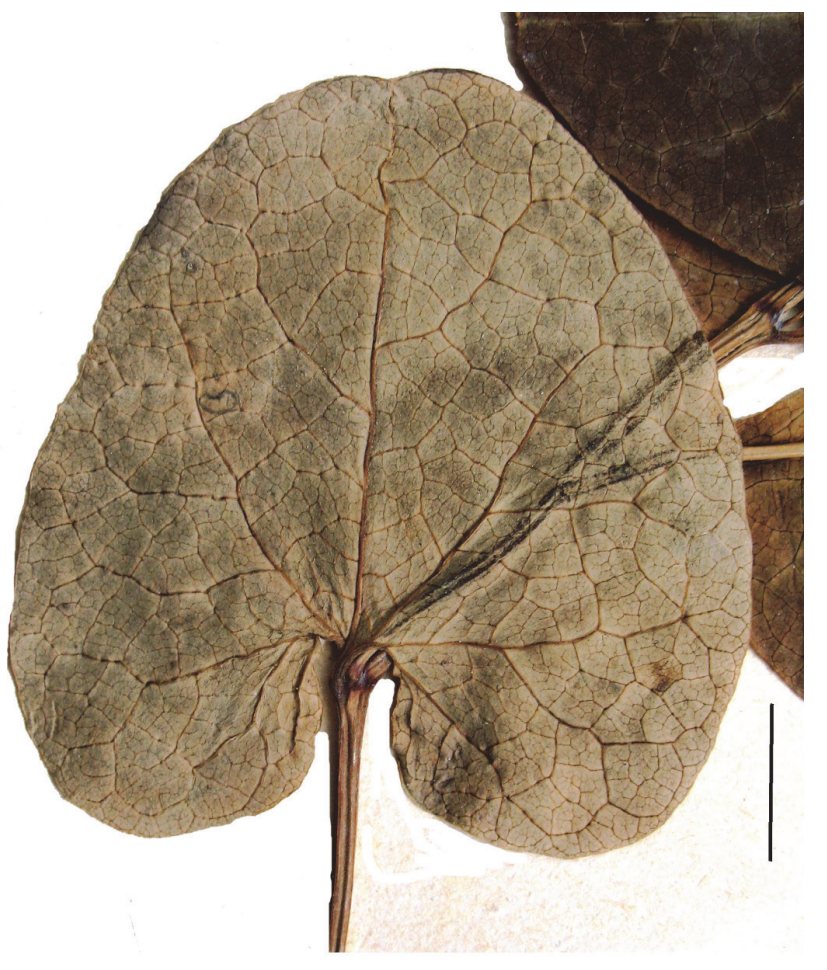

4

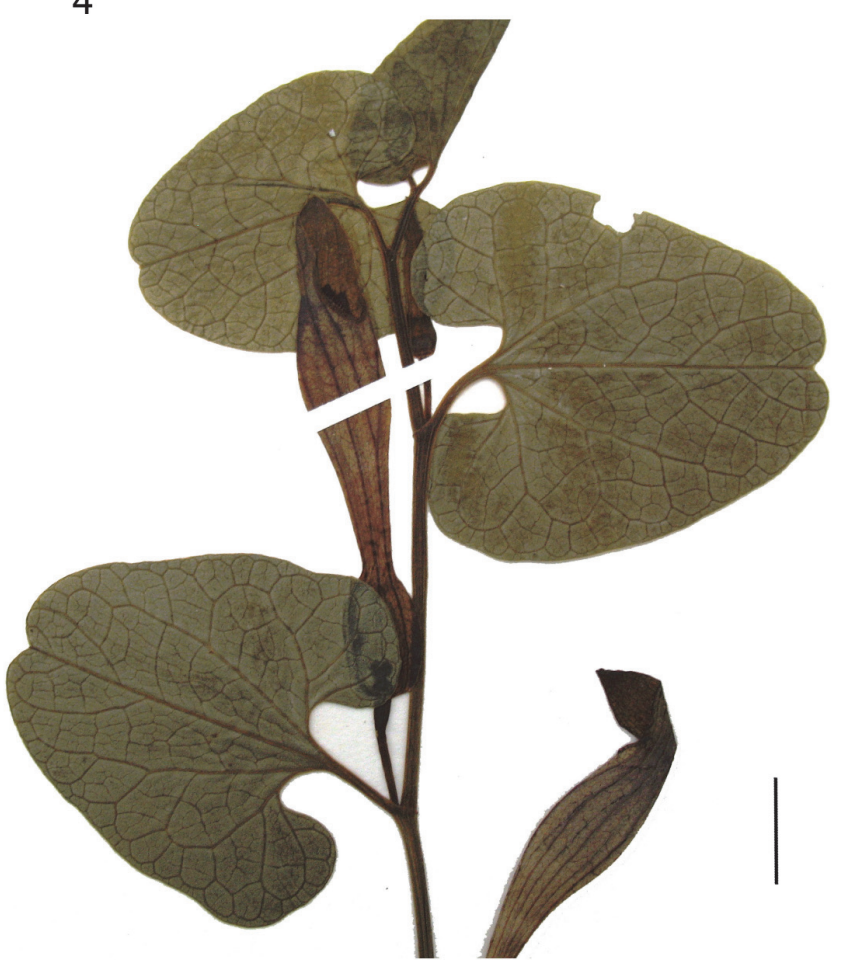

FIGURE 6. Examples of Aristolochia leaves of extant species, all scale bars $1 \mathrm{~cm}$. 1. A. sempervirens Linnaeus, 1753 (W 1889-284039, see also Figure 7). 2-4. A. rotunda Linnaeus, 1753 (6.2. W 1956-08094, 6.3. W 1976-06490, 6.44. W 1966-12346). 5. A. baetica Linnaeus, 1753 (W Herbar Jacq. Fil., see also Figure 9.1). 
form. Nevertheless, venation of Asarum Linnaeus, 1753 leaves is composed of distinct arching structures, which are less abundant, -developed and distinct in Aristolochia.

\section{Comparisons with Leaves of Other Plant Families}

Leaves similar in general appearance to those of the new species occur not only within the Aristolochioideae but also in the Convolvulaceae, Smilacaceae, Dioscoreaceae, Menispermaceae, Melastomataceae and Polygonaceae; however their venation is distinct or slightly different from that of Aristolochia. The Smilacaceae, Dioscoreaceae and Melastomataceae have, in general, a distinctly acrodromous or campylodromous venation with several mainly parallel primary veins, which join together apically (e.g., Klucking, 1995, plates 6-10). Within the Menispermaceae the lateral primary veins are either actinodromous or palinactinodromous (Klucking, 1995, plates 11-12). Within the Polygonaceae, the leaves of the genera Oxyria Hill, 1765 and Fallopia Adanson, 1763 show a similar leaf type and actinodromous venation as do the leaves of the genus Dichondra J.R. Forster and G. Forster, 1775 of the Convolvulaceae. But Oxyria leaves differ by their basal lamina margin, which is not built by the lateral primary veins as in the new fossil Aristolochia species. Fallopia leaves have secondary veins in the lower part of the leaf and Dichondra has several primary veins. With its distinctly lobate base the convolvulaceous genus Calystegia R. Brown, 1810 appears to be more similar, but the leaf apex and shape of the basal lobes are often slightly acute and the lobes are laterally directed. The lateral primary or secondary downwards running veins form well-developed arches, which are less well developed in the fossils. The saururaceous genus Saururus Linnaeus, 1753, a wetland plant whose fruits and seeds commonly found in the Miocene of Austria, might be considered a likely candidate. However, the ovate lobate lamina has sometimes secondary veins of sinuous-like course arising from the primary vein at an acute angle and the first secondary veins of these originate only in a short distance from the base. The character combination of the new species such as broad ovate to circular lamina shape, wide basal lobes, which are directed downwards, actinodromous venation, large distance between lamina base and first secondary veins at the midvein, basal part of the lateral primary veins building the lamina margin, and retuse lamina apex are found in Aristolochia only.

\section{Systematic-Taxonomic Discussion of the Fossil Aristolochia Species}

Several of the previously mentioned Aristolochia species from Europe, North America and Asia are of doubtful status, and some of the species were already referred to other genera (Knowlton, 1919; LaMotte, 1944, 1952; van der Burgh, 2005) as e.g., Aristolochites brittoni (Knowlton, 1922) Dorf, 1942 instead of Aristolochia brittoni Knowlton, 1922. The genus Aristolochites Heer in Capellini and Heer, 1867 was established for dentate leaves similar to Nymphaeaceaea and Aristolochiaephyllum Fontaine, 1889 for unidentifiable leaf fragments. Other fossil species were recombined with other genera of other families. Aristolochia crassifolia (Newberry, 1868) Cockerell, 1908 ( = A. cordifolia Newberry, 1898) was recombined to Paranymphaea Berry, 1935 (Nymphaeaceae), which was later put into the Polygonaceae (Mclver and Basinger, 1993), while A. aesculapi Heer, 1856 was transferred to Diversiphyllum Bůžek, 1971 and tentatively assigned with a question mark to the Convolvulaceae. The leaves of Diversiphyllum aesculapi (Heer, 1856) Bủžek, 1971 from the Petipsy area (Czech Republic, Miocene) are very variable in shape, but none of those are similar to the fossils from Pellendorf.

Schimper (1872) already listed different Aristolochia species and noted also his opinion about them. Two taxonomic problems are notable there. The leaf remains with crenate-dentate leaf margins from the Cretaceous of Nebraska belong in his opinion to "Aristolochia dentata Heer" despite the fact, that Heer (Capellini and Heer, 1867) determined them as Aristolochites dentata. Aristolochia dentata was primarily founded by Weber (see above) and Schimper (1872) established another superfluous species name Aristolochia serrata, based on $A$. dentata in Wessel and Weber (1856). A dentate margin like in $A$. dentata from Rott has not been observed in extant Aristolochia species. Rarely an undulate margin or minutely toothed laminae (Nardi, 1984) have been observed in extant species. The generic name Aristolochites was also used for fossil fruits from the Miocene of Vermont (Perkins, 1904).

In 1890 Schimper and Schenk regarded the fossil Aristolochia leaves that had been reported until that time to be "unsuitable for any determination or with a different venation type" (translated). Also $A$. venusta and $A$. inaequalis are doubtful in their opinion, because extant Aristolochia leaves all have symmetrical bases and the venation is different. Their conclusions were founded on their 


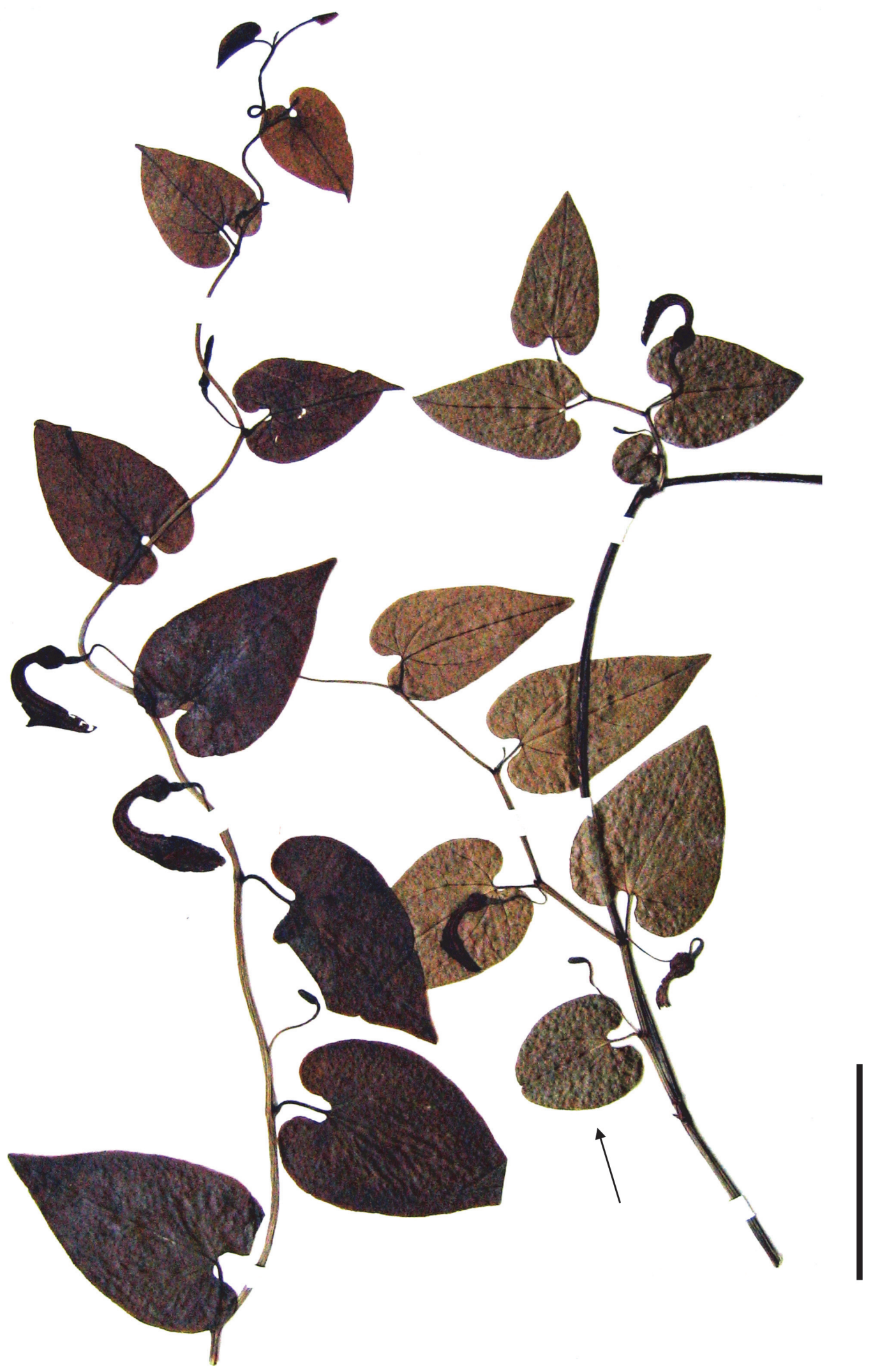

FIGURE 7. Voucher of Aristolochia sempervirens Linnaeus, 1753 (W 1889-284039) with a leaf of different shape at the base of one shoot (arrow); this leaf is figured in Figure 6.1 , scale bar $5 \mathrm{~cm}$. 

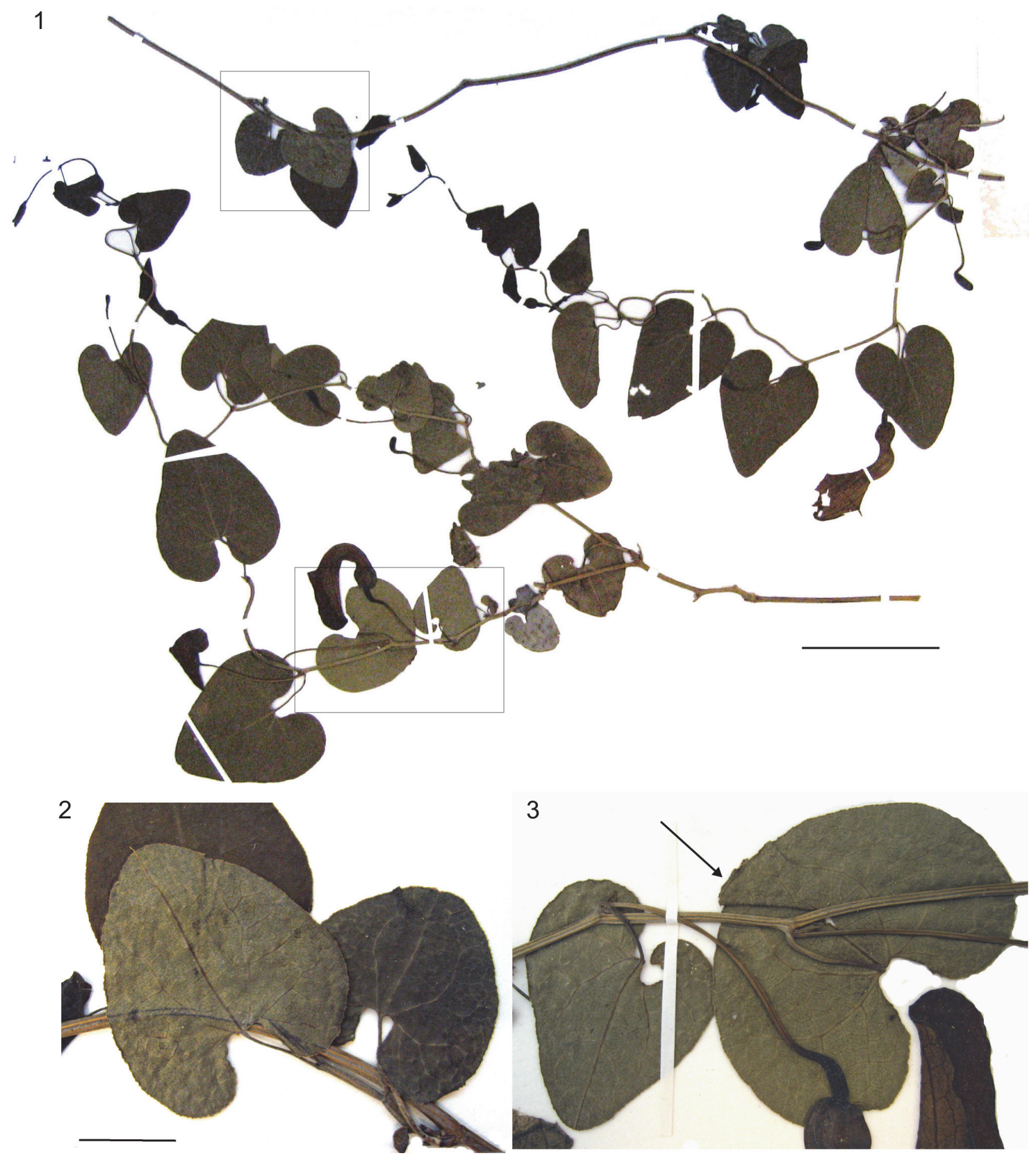

FIGURE 8. Voucher of Aristolochia baetica Linnaeus, 1753 (W 1970-10884). 1. overview of two stems, scale bar 5 $\mathrm{cm}$. 2. two normal leaves, detail of the upper stem, scale bar $1 \mathrm{~cm}$. 3. one normal leaf type and one wider and infolded leaf (arrow), detail of the lower stem, scale bar $1 \mathrm{~cm}$.

detailed study of several extant Aristolochia species and can be confirmed by the present study. The species name $A$. venusta might be a nomen nudum according to Knobloch (1998). He was unable to find any original publication of Saporta establishing this name, although the species was mentioned and figured by Schimper (1874). The leaves are very similar to leaves of extant Aristolochia species such as $A$. sempervirens but also similar to Asarum blumei Duchartre, 1864.

The palaeobotanical collections of the Natural History Museum in Leiden includes one leaf and 
1

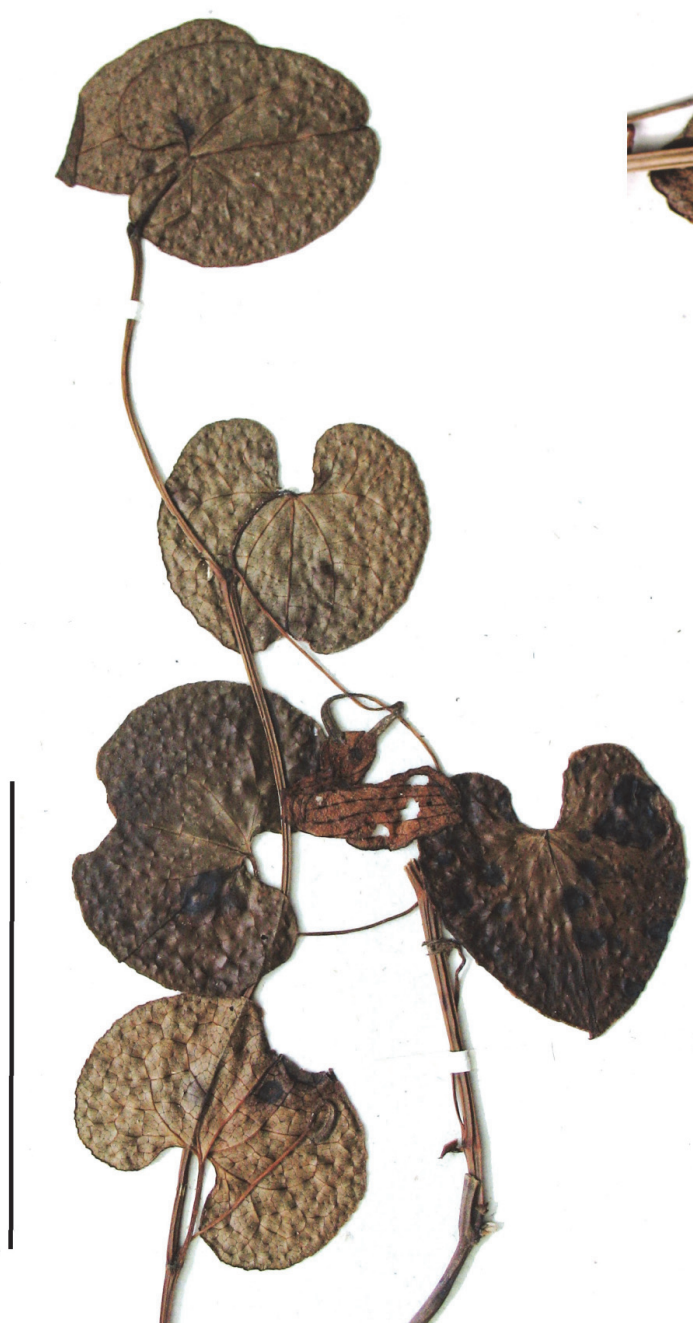

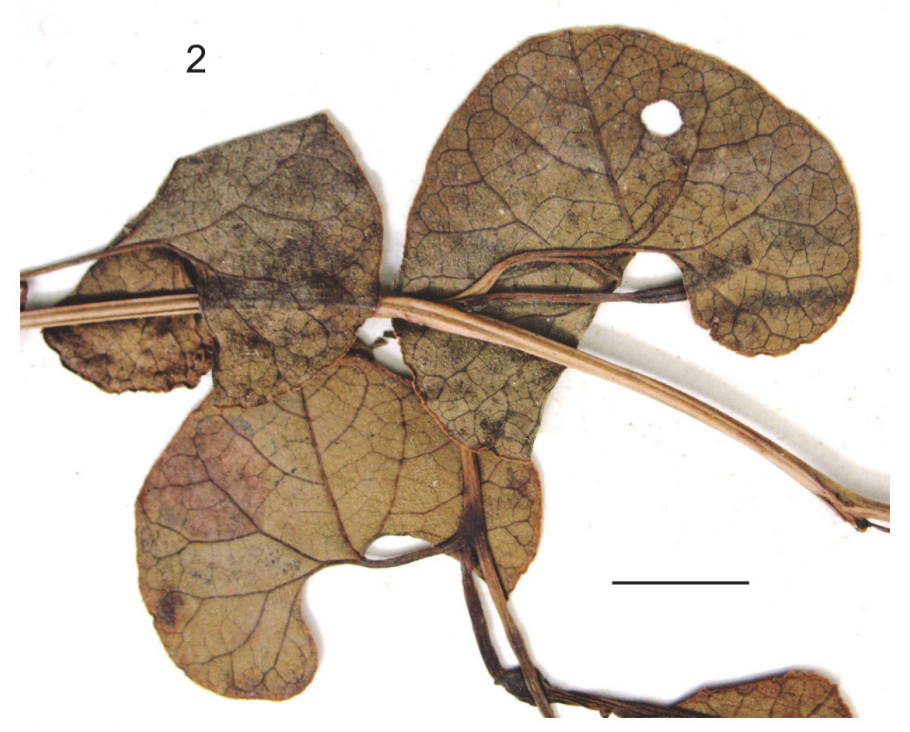

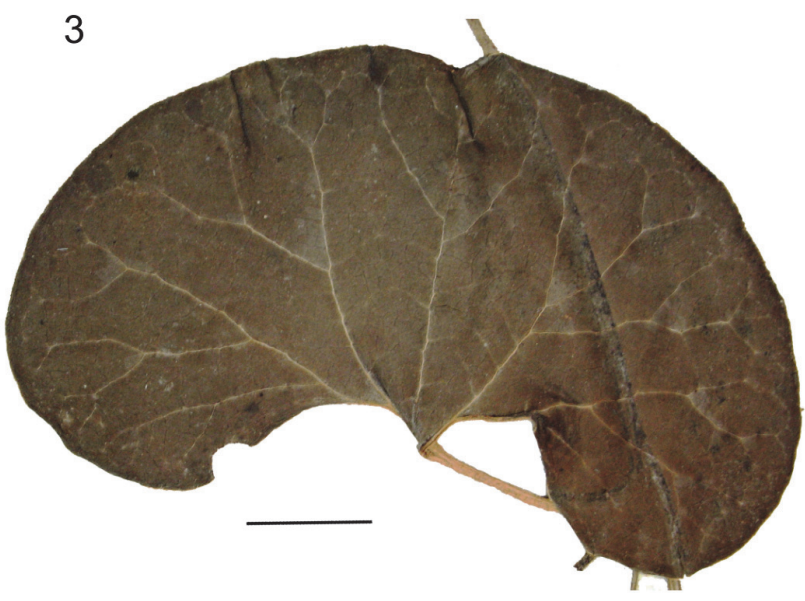

FIGURE 9. Examples of Aristolochia species with small and wide leaves. 1. A. baetica Linnaeus, 1753 (W Herbar. Jacq. Fil.), the upper leaf is figured in Figure 6.5 in detail, scale bar $5 \mathrm{~cm}$. 2. A. bridgesii (Klotzsch) Duchartre, 1864 (W Herb. Cuming.), scale bar $1 \mathrm{~cm}$. 3. A. chilensis Bridges ex Lindley, 1834 (W H. Endl. Chili-Cuming), scale bar 1 $\mathrm{cm}$.

one fruit of $A$. aesculapi from Leoben (Austria), which could be the type material of Ettingshausen, who described this species from Styria (1888, plate 4 , figure 32). The stored leaf and the figured leaf seem to be different specimens. Neither is similar to the new species or to the extant Aristolochia. The basal lobe of the figured leaf is of triangular shape and the secondary veins occur already in the lower part of the lamina. The leaf which is stored in Leiden is incomplete in its upper part and the base is asymmetrical with a lobe only at one side. It cannot be judged if the other part of the base is incomplete. The stored fruit impression, labelled as type material, looks similar to Aristolochia fruits, but the specimen figured by Ettingshausen $(1888$, plate 4 , figure 33 ) is less similar. This record as well as the fruit impression from Öhningen, $A$. oeningensis Heer, 1856, were regarded as doubtful by Kirchheimer (1957).

\section{DISCUSSION}

\section{Ecological and Taphonomical Reconsiderations}

The Pellendorf ecosystem consisted of different wetland habitats reflected by the invertebrate 
and plant assemblages with few records indicating zonal vegetation (Harzhauser et al., 2003, KovarEder et al., 2002 and unpublished material). Other plant assemblages from the Hollabrunn-Mistelbach Formation are rare, reflecting aquatic habitats (Kovar, 1979, Rohrbach) or indicating a speciespoor mesophytic forest (Kovar-Eder, 1988, Ebersbrunn) with leaf impressions of Quercus kubinyi (Kovats, 1851 ex Ettingshausen, 1852) Berger, 1952 or impressions of involucres of Carpinus pyramidalis Gaudin in Gaudin and Strozzi, 1858. Two palynological samples (preliminary studied by C.-C. Hofmann) include numerous wetland elements but also abundant pollen grains of Abies, Picea, Tsuga, Pinus and Cathaya. Pollen grains of Fagaceae, Tilia, Mastixia, Oleaceae, Engelhardia, Platycarya, Acer, Carya, Parthenocissus, small Caryophyllaceae, and clumps of Hamamelidaceae are rare. The habitat of $A$. austriaca was more likely to have been a wetland forest than a mesophytic forest. However, a mesophytic forest with mainly deciduous trees can be postulated in the hinterland areas, as indicated by other leaf assemblages in the Late Miocene of Austria (e.g., KovarEder, 1988). If Aristolochia belonged to the wetland ecosystem, it must have been a rare accessory element growing not directly at the water margin, hence the sparsity of fossils. The good preservation of the leaves points to a short transport distance, also indicating a wetland habitat or a drier habitat within the wetlands, like hammocks, or other special edaphic conditions. Its growth form might have been herbaceous or a shrubby liana, in accordance with the growth forms of extant species. A. baetica and $A$. sempervirens represent the only evergreen lianas of Aristolochia in the Mediterranean area whereas all the other Mediterranean species are herbaceous. Lianas are the general growth form of the tropical Aristolochia species. With the exception of aquatic plants, leaves of herbs are rarely fossilised, because of their often thinner texture and the fact that they are not abscissed. Also leaves of evergreen plants are generally rarer in the fossil record than leaves of deciduous plants.

The lack of fossil Aristolochia seed and fruit remains is remarkable, because winged seeds and fruits occur regularly in fossil leaf assemblages (e.g., Kovar-Eder, 1988, Carpinus, Fraxinus, Acer). Only few problematic Aristolochia fruit impressions were described yet. Many extant Aristolochia species have winged seeds which might be adapted to wind dispersal but can also allow floating on a water surface for a longer time. Hydrochory is men- tioned for $A$. clematitis although the seed is not winged (Huber, 1993). Unwinged seeds are often triangular or deltoid with a smooth or sculptured surface. Many, mainly herbaceous species have developed an elaiosome, an adaptation to myrmecochory. It might be plausible that the fossil Aristolochia species were rare herbaceous elements whose seeds had no wings.

\section{Systematic Relationship and Palaeogeographic Considerations}

A neotropical origin of the palaeotropical and Mediterranean Aristolochiaceae species was assumed by Neinhuis et al. (2005). A striking feature today is the endemism of Aristolochia not only in the Mediterranean (e.g., Nardi, 1984, 1991) but also in Africa and South and Central America (Schmidt, 1935). Wang (1992) considered that $A$. debilis originated in SW China and according to the investigations of Wanke (2006) $A$. debilis and $A$. clematitis were grouped together in a separate clade distinguishable from all Mediterranean species. Huber (1985) believed that the group with sessile utricles, to which $A$. clematitis belongs, has their centre of distribution in Asia Minor.

Wanke (2006) and Mahfoud (2009) regarded the Mediterranean area together with the Caucasus and the Near East as the centre of diversity of the Aristolochia species in the northern hemisphere, with about 60 species. They also proposed several phases of colonisation for the extant Mediterranean species complexes and fragmentation of larger distribution areas by isolation, explaining e.g., the distribution pattern of $A$. sempervirens in the eastern Mediterranean and $A$. baetica in the western part. Rikli $(1943,1946)$ already regarded the Aristolochiaceae as hygrophytic elements and remains of former vegetation within a more humid climate. The occurrence of some species in rocky dry habitats today was explained as a modern adaptation which fit the modern results.

It might be assumed, that Aristolochia survived in Mediterranean or Asia Minor refuges during the ice ages and re-established itself in postglacial times. However, the Quaternary history of Aristolochia remains speculative because of the lack of pollen records (Draxler, Drescher-Schneider, personal commun., 2013). Lang (1994) did not mention anything about the genus.

The evolutionary history of the Aristolochiaceae during the Cretaceous and Tertiary remains a most interesting question. The few reliable fossil records such as the Aristolochioideae pollen grains in Late Cretaceous sediments of Siberia, Late Mio- 
cene leaf impressions of Aristolochia in Austria and maybe a few others in Europe and America are not sufficient to reconstruct the palaeogeographical distribution and migration routes. More reliable fossil records are necessary for the solution of this problem.

\section{ACKNOWLEDGEMENTS}

This study has been thankfully supported by many colleagues and institutes: T.C. Fischer (Munich) for his help during the fieldwork, $Z$. Kvaček (Prague) for providing information about material from the Czech Republic, M. Pinka (Zürich) for checking the collection for Heer's type specimens, J. van Konijnenburg-van Cittert for providing pictures of specimens from Leoben stored in the Natural History Museum Leiden, C.-C. Hofmann (Vienna) who investigated two palynological samples, F. Grimsson (Vienna) for his help with the ages of the Greenland floras, and D.K. Ferguson (Vienna) for improving the English and some helpful comments.

The staffs at the libraries of the Geological Survey Austria, the Natural History Museum Vienna (Botanical and Geological departments) and the University Vienna (Libraries of Botany and Earth Sciences) are thanked for their help. The Geological Survey Austria supported financially the travels to Prague and Gainesville, while I. Draxler (former head of the Department of Palaeontology and Collections) encouraged the study. Many thanks also to the staff of the herbarium of the Natural History Museum Vienna, the herbarium of the Botanical Institute of the University of Vienna and Herbarium University of Florida at Gainesville for their support during my comparative studies. The Geological Survey of the Czech Republic (Prague) gave permission to study the type material of Diversiphyllum Bůžek, 1971. The Institute of Palaeontology at the University of Vienna provided the facilities to finish this investigation. Two reviewers provided helpful comments improving the manuscript.

\section{REFERENCES}

Adanson, M. 1763. Familles des Plantes 2. Vincent, Paris.

Andreánszky, G. 1959. Die Flora der sarmatischen Stufe in Ungarn. Akademie Kiadó, Budapest.

APGII 2003. An update of the Angiosperm Phylogeny Group classification for the orders and families of flowering plants: APG II. Botanical Journal of the Linnean Society, 141:399-436.
APGIII 2009. An update of the Angiosperm Phylogeny Group classification for the orders and families of flowering plants: APG III. Botanical Journal of the Linnean Society, 161:105-121.

Barringer, K. 1997. Aristolochia. In Flora of North America Editorial Committee (eds.), Flora of North America North of Mexico, Volume 3, New York and Oxford. www.efloras.org/florataxon.aspx?flora_id=1\&taxon_id=102606)

Berchtold, F. and Presl, J.S. 1820. O prirozenosti Rostlin. K.W. Endersa, Praha.

Berger, W. 1952. Die altpliozäne Flora der CongerienSchichten von Brunn-Vösendorf bei Wien. Palaeontographica B, 92:79-121.

Berry, E.W. 1924. The middle and upper Eocene floras of southeastern North America. U.S. Geological Survey Professional Paper, 92:1-205.

Berry, E.W. 1935. A preliminary contribution to the floras of the Whitemud and Ravenscrag formations. Canada Geological Survey Mémoirs, 182:1-107.

Boissier, P.E. and Spruner, W.v. 1844. Diagnoses Plantarum Orientalium novarum, ser. 1, 5. Herrmann, Leipzig

Brown, N.E. 1886. Gardeners' Chronicle, n. s. 26. London

Brown, R. 1810. Prodromus Florae Novae Hollandiae et Insulae van-Diemen. Richard Taylor \& Son, London.

Bůžek, Č. 1971. Tertiary flora from the northern part of the Petipsy area (North-Bohemian Basin). Rozpravy Ústredního ústavu geologického, 36: 1-118.

Capellini, J. and Heer, O. 1867. Les phyllites crétacées du Nebraska. Neue Denkschriften der Allgemeinen schweizerischen Gesellschaft für die gesamten Naturwissenschaften, 22:1-24.

Chandler, M.E.J. 1957. The Oligocene flora of the Bovey Tracey Lake Basin, Devonshire. Bulletin of the British Museum of Natural History, 3:73-123.

Chaney, R.W. and Sanborn, E.I. 1933. The Goshen Flora of West Central Oregon. Contributions to Paleontology, Carnegie Institution of Washington Publication, 439:1-103.

Cockerell, T.D.A. 1908. The fossil flora of the Florissant, Colorado. Bulletin of the American Museum of Natural History, 24:71-110.

Davis, P.H. and Khan, M.S.1964. Two new Aristolochias from Turkey. Notes of the Royal Botanic Garden, Edinburgh, 25:67-69.

Dorf, E. 1942. Upper Cretaceous floras of the Rocky Mountain Region II. Flora of the Lance Formation at its type locality, Niobrara County, Wyoming. Contributions to Palaeontology II, Carnegie Institution of Washington Publication, 508:81-168.

Duchartre, P.É.S. 1854. Annales Sciences Naturelles; Botanique, sér. 4, 2. Fortin, Masson, Paris.

Duchartre, P.É.S. 1864. Prodromus Systematis Naturalis Regni Vegetabilis 15. Treuttel et Würtz, Paris. 
Ettingshausen, C.v. 1852. Fossile Pflanzenreste aus dem trachytischen Sandstein von Heiligenkreutz bei Kremnitz. Abhandlungen der kaiserlich königlich geologischen Reichsanstalt, 1:1-14.

Ettingshausen, C.v. 1888. Die fossile Flora von Leoben in Steiermark. Denkschriften der kaiserlichen Akademie der Wissenschaften, mathematisch - naturwissenschaftliche Classe, 54:1-58.

Fischer, M.A.E., Oswald, K., and Adler, W. 2008. Exkursionsflora für Österreich, Liechtenstein, Südtirol. Oberösterreichisches Landesmuseum, Linz.

Fontaine, W.M. 1889. The Potomac or Younger Mesozoic Flora. U.S. Geological Survey monographs, 15: 1-377.

Forster, J.R. and Forster, G. 1775. Characteres Generum Plantarum. B. White, T. Cadell, \& P. Elmsly, London.

Gaudin, C.-T. and Strozzi, C. 1858. Mémoires sur quelques gisements de feuilles fossiles de la Toscane. Neue Denkschriften der allgemeinen schweizerischen Gesellschaft der gesamten Naturwissenschaften, 16:1-47.

Givulescu, R. and Ticleanu, N. 1978. Neue und interessante Pflanzen aus dem Fundort Chiuzbaia (Maramures). Studii si comunicare Muzeum Brukenthal, 22:43-52.

Gregor, H.-J. and Knobloch, E. 2001. Die oligozänen Floren von Santa Giustina und Sassello (Ligurien, Oberitalien): eine kritische Revision. Documenta Naturae - Flora Tertiaria Mediterranea, 5:1-50.

Harzhauser, M., Kovar-Eder, J., Nehyba, S., StröbitzerHermann, M., Schwarz, J., Wojcicki, J., and Zorn, I. 2003. An early Pannonian (Late Miocene) Transgression in the Northern Vienna Basin. The Paleoecological feedback. Geologica Carpathica, 54:41-52.

Heer, O. 1856. Flora Tertiaria Helvetiae. Die tertiäre Flora der Schweiz. 2. Band. Die apetalen Dicotyledonen. J. Wurster and Compagnie, Winterthur.

Heer, O. 1859. Flora Tertiaria Helvetiae. Die tertiäre Flora der Schweiz 3. Band. Die gamopetalen und polypetalen Dicotyledonen. J. Wurster and Compagnie, Winterthur.

Heer, O. 1874. Nachträge zur miozänen Flora Grönlands. Kungliga Svenska Vetenskapsakademiens Handlinga, 13(2): 1-29.

Heer, O. 1883. Die fossile Flora der Polarländer: 2. Teil der fossilen Flora Grönlands, Flora fossilis arctica. J. Wurster and Compagnie, Zürich.

Hemsley, W.B. 1885. Journal of Botany, British and Foreign, 23. West, Newman \& Co., London

Hickey, L.J. 1979. A revised classification of the architecture of dicotyledonous leaves, p. 25-30. In Metcalfe, C.R. and Chalk, J. (eds.), Anatomy of the Dicotyledons, Vol. 1, Clarendon Press, Oxford.

Hill, J. 1765. The vegetable system. Vol. X, Containing all the One-Petal'd plants with Six, Seven, and many Segments: And the Two entire classes of Two-Petal'd and Three-Petal'd Plants. London.
Hofmann, C.-C. and Zetter, R. 2010. Upper Cretaceous sulcate pollen from the Timerdyakh Formation, Vilui Basin (Siberia). Grana, 49:170-193.

Hollick, A. and Martin, G.C. 1930. The Upper Cretaceous Floras of Alaska. U.S. Geological Survey Professional Paper, 159:1-117.

Hou, D. 1983. Florae malesianae praecursores LXV. Notes on Aristolochiaceae. Blumea, 29:223-249.

Huber, H. 1985. Samenmerkmale und Gliederung der Aristolochiaceen. Botanisches Jahrbuch für Systematik, 107:277-320.

Huber, H. 1993. Aristolochiaceae. p. 129-137. In Kubitzki, K. (ed.), The Families and genera of Vascular Plants II. Springer Verlag, Berlin, New York.

IPNI 2012. The International Plant Name Index. Published on the Internet www.ipni.org [accessed 1 July 2012].

Jacquin, N.J.v. 1760. Enumeratio Systematica Plantarum, 30. T. Haack, Leiden

Jussieu, A.L. 1789. Genera plantarum : secundum ordines naturales disposita, juxta methodum in Horto regio parisiensi exaratam, anno M.DCC.LXXIV. Herrisant, Barrois, Paris.

Kirchheimer, F. 1936. Beiträge zur Kenntnis der Tertiärflora. Früchte und Samen aus dem Deutschen Tertiär. Palaeontographica B, 82:73-141.

Kirchheimer, F. 1957. Die Laubgewächse der Braunkohlenzeit. Knapp, Halle.

Klucking, E.P. 1995. Leaf venation patterns Volume 7. The classification of leaf venation patterns. Cramer, Berlin.

Knobloch, E. 1998. Der pliozäne Laubwald von Willershausen am Harz (Mitteleuropa). Documenta Naturae, 120:1-302.

Knowlton, F.H. 1917. Geology and Paleontology of the Raton Mesa and other regions in Colorado and New Mexico. Fossil Floras of the Vermejo and Raton Formations of Colorado and New Mexico. U.S. Geological Survey Professional Paper, 101:223-349.

Knowlton, F.H. 1919. A catalogue of the Mesozoic and Cenozoic plants of North America. U.S. Geological Survey Bulletin, 696:1-815.

Knowlton, F.H. 1922. The Laramie Flora of the Denver Basin. U.S. Geological Survey Professional Paper, 130:1-175.

Kovar, J. 1979. Pflanzenreste aus dem Pannon (OberMiozän) von Rohrbach bei Ziersdorf (Niederösterreich). Beiträge zur Paläontologie, 6:107-111.

Kovar-Eder, J. 1988. Obermiozäne (Pannone) Floren aus der Molassezone Österreichs. Beiträge zur Paläontologie, 14:19-121.

Kovar-Eder, J., Schwarz, J. and Wojcicki, J. 2002. The predominantly aquatic flora from Pellendorf, Lower Austria, Late Miocene, Pannonian - a systematic study. Acta Palaeobotanica, 42: 15-151.

Kovats, J.v. 1851. Fossile Flora von Erdöbenye. Jahrbuch der kaiserlich königlich geologischen Reichsanstalt, 2(2):178. 
Kvaček, Z., Böhme, M., Dvorák, Z., Konzalová, M., Mach, K., Prokop, J., and Rajchl, M. 2004. Early Miocene freshwater and swamp ecosystems of the Most Basin (northern Bohemia) with particular reference to the Bilina mine section. Journal of the Czech Geological Society, 49:1-40.

Lamarck, J.B.A.P. 1783. Encyclopedie Methodique. Botanique, Paris.

LaMotte, R.S. 1944. Supplement to the catalogue of the Mesozoic and Cenozoic plants of North America 1919-37. U.S. Geological Survey Bulletin, 924: 1330.

LaMotte, R.S. 1952. Catalogue of the Cenozoic plants of North America through 1950. Memoirs of the Geological Society of America, 51:1-381.

Lang, G. 1994. Quartäre Vegetationsgeschichte Europas. Fischer, Jena.

Lauber, K. and Wagner, G. 1996. Flora Helvetica. Haupt, Bern, Wien.

Lindley, J. 1834. Edwards's Botanical Register, 20. Ridgway, London.

Linnaeus, C.v. 1753. Species Plantarum 2. Laurentius Salvius, Stockholm.

Lojacono, M. 1907. Flora Sicula o Descrizione delle Piante Vascolari Spontanee o Indigenate Sicilia, 2, 2. Palermo

Ludwig, R. 1859-1861. Fossile Pflanzen aus der ältesten Abteilung der Wetterau-Rheinischen Tertiär-Formation. Palaeontographica, 8 (in several parts):39-154.

MacGinitie, H.D. 1937. The flora of the Weaverville beds of Trinity County, California with descriptions of the plant-bearing beds. Contributions to Palaeontology, Carnegie Institution of Washington Publication, 465:83-151.

Mahfoud, H.M. 2009. Evolution of the genus Aristolochia (Aristolochiaceae) in the Eastern Mediterranean including the Near East and Caucasia. PhD Thesis, Technische Universität Dresden. nbn-resolving.de/ urn:nbn:de:bsz:14-qucosa-27142)

Mai, D.H. 1995. Tertiäre Vegetationsgeschichte Europas. Gustav Fischer Verlag, Jena.

Mclver, E.E. and Basinger, J.F. 1993. Flora of the Ravenscrag Formation (Paleocene), Southwestern Saskatchewan, Canada. Palaeontographica Canadiana, 10:1-85.

Miki, S. 1941. On the change of flora in Eastern Asia since Tertiary period (1). The clay or lignite beds flora in Japan with special reference to the Pinus trifolia beds in Central Hondo. Japanese Journal of Botany, 11:237-303.

Miki, S. 1960. Nymphaeacae remains in Japan with new fossil genus Eoeuryale. Journal of the Institute of Polytechechnics, D11:63-78.

Nardi, E. 1984. The genus Aristolochia L. (Aristolochiaceae) in Italy. Webbia, 38:221-300.

Nardi, E. 1991. The genus Aristolochia L. (Aristolochiaceae) in Greece. Webbia, 45:31-69.
Nardi, E. and Arrigoni, P.V. 1983. Le piante endemiche della Sardegna. 134-135. - 134. Aristolochia tyrrhena, species nova. - 135. Aristolochia insularis, species nova. Bollettino Societa Sarda Scienze Naturali. 22: 347-356.

Neinhuis, C., Wanke, S., Hilu, K. W., Müller, K., and Borsch, T. 2005. Phylogeny of Aristolochiaceae based on parsimony, likelihood, and Bayesian analyses of trnL-trnF sequences. Plant Systematic and Evolution, 250:7-26.

Newberry, J.S. 1868. Note on the later extinct floras of North America, with descriptions of some new species of fossil plants from the Cretaceous and Tertiary. New York Lyceum Natural History Annals, 9:1-76.

Newberry, J.S., posthumous work ed. by A. Hollick 1898. The later extinct floras of North America. U.S. Geological Survey Monographs, 35:1-295.

Parodi, D. 1878. Anales Sociedad Cientifica Argentina, 155 (Contrib. 47). Pablo E. Coni é Hijos, Buenos Aires.

Parsons, M.J. 1996. New species of Aristolochia and Pararistolochia (Aristolochiaceae) from Australia and New Guinea. Botanical Journal of the Linnean Society, 120:199-238.

Perkins, G.H. 1904. Report of the state geologist on the Mineral Industries and Geology of Certain Areas of Vermont. 1903-1904. Montpelier, Vermont.

Pfeifer, H.W. 1966. Revision of the north and central American hexandrous species of Aristolochia (Aristolochiaceae). Annals of the Missouri Botanical Garden, 53:1-114.

Principi, P. 1916. Le Dicotiledoni Fossili des Giacimento Oligocenico di Santa Giustina e Sasselo in Liguria. Memorie alla descrizione della Carta Geologica d'Italia, 6:1-207.

Rikli, M. 1943. Das Pflanzenkleid der Mittelmeerländer I. Huber, Bern.

Rikli, M. 1946. Das Pflanzenkleid der Mittelmeerländer II. Huber, Bern.

Schimper, W.P. 1872. Traité de paléontologie vegétale ou la flore du monde primitif dans ses rapports avec les formations géologiques et la flore du monde actuel, tome 2. J.B. Baillière et fils, Paris.

Schimper, W.P. 1874. Traité de paléontologie végétales ou la flore du monde primitif dans ses rapports avec les formations géologiques et la flore du monde actuel, tome 3. J.B. Baillière et fils, Paris.

Schimper, W.P. and Schenk, A. 1890. Palaeophytologie. Handbuch der Paläontologie. R. Oldenbourg, München-Leipzig.

Schmidt, O. 1935. Aristolochiaceae, p. 204-242. In Engler, A. and Harms, H. (eds.), Die natürlichen Pflanzenfamilien. Wilhelm Engelmann Verlag, Leipzig.

Sennen, E. (Frère) and Pau, C. 1911. Butlletí Institució Catalana d'Història Natural 1911:19. 
Shumei, H., Kelly, L.M., and Gilbert, M.G. 2003. Aristolochiaceae, p.246-269. In Zhengyi, W. and Raven, P. (eds.), Flora of China, Ulmaceae through Basellaceae 5. Science Press Bejing, Missouri Botanical Garden Press, St. Louis.

Sun, B. 1999. Shanwang fossil plants. Shandong Science and Technology Press, Ji'nan.

Takhtajan, A. (ed.) 1974. Magnoliophyta fossilia URSS, Vol. 1. Nauka, Leningrad.

Taylor, T.N., Taylor, E.L., and Krings, M. 2009 Paleobotany. The Biology and evolution of fossil plants (2nd ed.). Academic Press, Elsevier, Burlington.

The Plant List 2010. Version 1. Published on the Internet; www.theplantlist.org/ (accessed 1st January).

Vahl, M. 1794. Symbolae Botanicae 3:99. Nicolas Müller et Filius, Königssaal.

van der Burgh, J. 2005. Index of Angiosperm leaf species names $A-B$, 1823-2000. Fossilium Catalogus II, Plantae pars 107. Backhuys Publishers, Leiden.
Wang, W.-T. 1992. On some distributions and some migration routes found in the eastern Asiatic region. Acta Phytotaxonomica Sinica, 30(1):1-24 (in Chinese (not read) with English abstract).

Wanke, S. 2006. Evolution of the genus Aristolochia Systematics, Molecular Evolution and Ecology. PhD Thesis, Technische Universität Dresden. nbn-resolving.de/urn:nbn:de:swb:14-1169634459488-35651

Wanke, S., Gonzalez, F., and Neinhuis, C. 2006. Systematics of the pipevines: combining morphological and fast-evolving molecular characters to investigate the relationships within subfamily Aristolochioideae (Aristolochiaceae). International Journal of Plant Sciences, 167:1215-1227.

Weber, C.O. 1852. Die Tertiärflora der Niederrheinischen Braunkohlenformation. Palaeontographica, 2:1-122.

Wessel, P. and Weber, C.O. 1856. Neuer Beitrag zur Tertiär-Flora der niederrheinischen Braunkohlenformation. Palaeontographica, 4:111-130, 131-168.

Willdenow, C.L. 1809. Mémoires de la Société Impériale des Naturalistes de Moscou 2:101, pl.6. 